\title{
GEOCHEMISTRY OF MAJOR ELEMENTS IN MIDDLE ORDOVICIAN CARBONATE ROCKS: COMPARATIVE ANALYSIS OF ALTERATION ZONES, NORTH ESTONIA
}

\author{
Liidia BITYUKOVAa, Alla SHOGENOVAa , Väino PUURAa, \\ Tõnis SAADRE ${ }^{b}$, and Kalle SUUROJA ${ }^{\mathrm{b}}$
}

a Geoloogia Instituut (Institute of Geology), Estonia pst. 7, IE-0001 Tallinn, Eesti (Estonia)

b Eesti Geoloogiakeskus (Geological Survey of Estonia), Pikk 67, EE-0001 Tallinn, Eesti (Estonia)

Received 23 August 1995, accepted 18 December 1995

\begin{abstract}
Altered and/or mineralized bodies formed due to secondary processes occur frequently in the early Palaeozoic carbonate deposits in Estonia. Selectively dissolved and leached rocks, karst cavities, metasomatic dolomite beds, and fracture-related unconformable bodies, calcite, sulphide, sulphate, and oxide minerals filling pore space (fractures, fissures, and caverns) are the most common phenomena. In the Middle Ordovician there were studied four alteration zones: three in limestones of the Väo Formation from the Väo and Harku outcrops, and one in the Viivikonna Formation from the Narva opencast. The content of 12 oxides $\left(\mathrm{CaO}, \mathrm{MgO}, \mathrm{FeO}, \mathrm{Fe}_{2} \mathrm{O}_{3}, \mathrm{~K}_{2} \mathrm{O}, \mathrm{Na}_{2} \mathrm{O}, \mathrm{SiO}_{2}, \mathrm{Al}_{2} \mathrm{O}_{3}\right.$, $\mathrm{TiO}_{2}, \mathrm{P}_{2} \mathrm{O}_{5}, \mathrm{SO}_{3}$, and $\mathrm{CO}_{2}$ ) in the sampled rocks was determined by the classical wetsilicate analysis and interpreted using the correlation analysis. Two geochemical types of dolomitization, and correspondingly two groups of rocks, can be defined considering the distribution of $\mathrm{CaO}, \mathrm{MgO}$, total iron, $\mathrm{Fe}^{2+}$ and $\mathrm{Fe}^{3+}$, and sulphur. The first group consists of background rocks almost untouched by dolomitization and those from the Väo Formation, which occur close to the fractures in the Harku outcrop (MgO concentration up to $4 \%, \mathrm{CaO} 42-52 \%$ ). The second clearly defined group comprises the almost fully dolomitized rocks of the Viivikonna Formation of the Narva opencast ( $\mathrm{MgO}$ concentration in these rocks is about $14-18 \%, \mathrm{CaO}$ makes $30 \%$ ). In the Väo outcrop and Narva opencast the $\mathrm{FeO}$ concentration is in positive correlation with that of $\mathrm{MgO}$. The results obtained are compared with the earlier studies of different authors.
\end{abstract}

Key words: alteration, dolomitization, fractures, carbonate rocks, chemical composition, correlation analysis, carbonate-sulphide mineralization, unconformities, Ordovician, Estonia.

\section{INTRODUCTION}

This study serves as the first stage in the complex petrophysical and geochemical investigation of early Palaeozoic carbonate rocks of Estonia. Below the chemical composition of rocks in the alteration zones is discussed and an attempt is made to classify altered rocks by geochemical data. Altered and/or mineralized bodies of distinct geological setting, caused by different-age secondary processes, are often found in the early Palaeozoic carbonate rocks in Estonia. Altered rocks are represented by metasomatic dolomite beds and fault-(fissure-) related unconformable dolomite bodies. Most commonly these are characterized by selectively 
dissolved and leached rocks, karst cavities, calcite, sulphide, sulphate, and oxide minerals filling pore space (fissures and caverns).

Samples for the study were taken from two vertical fracture-related dolomitization and mineralization zones in the limestones of the Väo Formation from the Väo outcrop and from a wide dolomitized zone of the same formation in the Harku outcrop. In the Narva opencast, a laterally extended leached and dolomitized body occurring beneath the OrdovicianDevonian unconformity in the limestones and kukersite oil shale of the Viivikonna Formation was sampled.

The concentration of 12 oxides $\left(\mathrm{CaO}, \mathrm{MgO}, \mathrm{FeO}, \mathrm{Fe}_{2} \mathrm{O}_{3}, \mathrm{~K}_{2} \mathrm{O}, \mathrm{Na}_{2} \mathrm{O}\right.$, $\mathrm{SiO}_{2}, \mathrm{Al}_{2} \mathrm{O}_{3}, \mathrm{TiO}_{2}, \mathrm{P}_{2} \mathrm{O}_{5}, \mathrm{SO}_{3}$, and $\mathrm{CO}_{2}$ ) in the rocks was determined by the classical wet-silicate analysis. The distribution of elements showed that the variation of the $\mathrm{CaO}, \mathrm{MgO}, \mathrm{FeO}, \mathrm{Fe}_{2} \mathrm{O}_{3}$, and $\mathrm{SO}_{3}$ concentration was definitely controlled by secondary processes. Changes in the content of other oxides in the rocks were mainly connected with the occurrence of various argillaceous admixtures, which indirectly influence the intensity of secondary processes. Using the correlation analysis, at least two different types of secondary altered carbonate rocks were revealed. Besides $\mathrm{CaO}$ and $\mathrm{MgO}$ substitutions, these are characterized by different relationships of total iron, $\mathrm{Fe}^{2+}$ and $\mathrm{Fe}^{3+}$, and sulphur. The fissure-filling calcite-sulphide mineralization has its own specific characteristics.

\section{GEOLOGICAL SETTING}

Since the beginning of the Palaeozoic, the territory of northern Estonia has been among the most stable areas of the East European platform subjected to very weak epeirogenic movements (Сувейдзис, 1979). On the territory of Estonia the Ordovician sequence is represented by shallow-water open shelf carbonate rocks ranging from 70 to $180 \mathrm{~m}$ in thickness (Männil, 1990). The uniform homocline structure of the OrdovicianSilurian carbonate complex is gently sloping (usually $2.9-4.4 \mathrm{~m} / \mathrm{km}$ ) to the south. Systems of faults and fractures complicating the homocline structure were formed in the studied region mainly due to the Palaeozoic tectonic processes taking place in the surrounding areas. Along these fracture systems, crosscutting both aquifers and aquitards, there occurred migration of fluids (deep and superficial) responsible for alteration and mineralization of deposits.

Altered and mineralized bodies have been described in the early Palaeozoic carbonate rocks from different localities (Möls, 1961; Baxep et al., 1962; Газизов, 1971; Pichugin et al., 1978; Вингисаap \& Таалманн, 1974; Niin et al., 1981; Шогенова \& Туулинг, 1990). In Silurian and Ordovician deposits there occur bodies of cavernous dolomites and limestones of various sizes formed through alteration of rocks. The altered rock bodies are commonly directed either vertically or horizontally due to tectonic (faults, fracture zones, fissures) or stratigraphical (unconformities, distinct beds) control, respectively. Selective solution and leaching of carbonate minerals and/or metasomatic substitution of $\mathrm{MgO}$ for $\mathrm{CaO}$ are the main evidences of zonal alteration processes. Secondary dolomite replaces sedimentary calcite (including fossil debris) in rocks. Secondary calcite fills the pore space (fissures, caverns) together with different iron sulphide, sulphate, oxide, and hydroxide minerals. Increased porosity, changes in colour and mineralization are the main observable macroscopic evidences of secondary processes. Fresh water infiltration and karst processes occurring at different times (from the early Palaeozoic to Holocene), and late Palaeozoic telethermal metasomatic dolomitization have been supposed as probable causes of alteration/mineraliz- 
ation, although there are cases of genetically unidentified dolomitization and leaching (Möls, 1961; Baxep et al., 1962; Газизов, 1971; Pichugin et al., 1978; Niin et al., 1981; Кийпли et al., 1984).

In the Ordovician and Silurian rocks of northern Estonia there prevail fairly pure detrital limestones. Based on geochemical studies, four types of Lower Palaeozoic sedimentary carbonate rocks were revealed by Kiipli et al. (Кийпли et a1., 1984), three of which included dolomitized rocks.

The first type was sampled and described from an areally dolomitized layer corresponding to the Pae Member of the Väo Formation. This layer has been studied earlier by different authors and described in detail by Kiipli (Кийпли, 1983a). In northern Estonia the Pae Member is represented by a distinct 0.2 -0.6-m-thick dolomite layer extending from west to east for over $200 \mathrm{~km}$.

The second type of secondary dolomites occurs in the Middle and Upper Ordovician (reaching also the Silurian in central Estonia) close to the erosional contact with Devonian carbonate and clastic or mixed deposits forming in large scale an unconformable body beneath the Devonian unconformity surface. The mineralogical composition of these rocks was studied in detail by Kleesment (Клеесмент et al., 1980).

The third type associated with tectonic disturbances is related to fracture zones (Baxep et al., 1962; Pichugin et al., 1978). Large zones of tectonic fracturing and dolomitization occur usually in the areas of both major and minor tectonic disturbances of NE, NS, and NW direction. The NE oriented zones are often discovered and described in NE Estonia (Газизов, 1958, 1971; Baxep et al., 1962; Пуура et al., 1987; Шогенова \& Туулинг, 1990).

The fourth type is related to separate fractures, which are often (mostly the NE oriented ones) filled by mineralization (Möls, 1961; Niin et al., 1981; Кийпли, 1983a). In the vicinity of Tallinn and in western Estonia, mineralization of fissures and fractures in limestones occurs with or without dolomitization of wall rocks.

Two groups of dolomites were distinguished based on their genesis: those formed during sedimentation processes and as a result of secondary alteration processes. The last type may be subdivided into early diagenetic and late diagenetic varieties (Russian term - catagenetic).

In the present study, which is a part of larger research, we tried to determine the geochemical signatures of different types of Lower Palaeozoic carbonate rocks by means of statistical correlation analysis. The study and comparison of the composition of altered and unaltered rocks in the local zones of disturbances is one way to classify and identify the carbonate rocks of complicated genesis.

\section{RESULTS}

Four different types of dolomitized bodies were sampled. The sampling scheme is given in Figs. $1-3$. Two thin altered rock zones (Fig. $1 A, B$ ) in fracture walls represent two varieties of fissure fillings in the Väo Formation (including a 0.6-m-thick dolomite layer of the Pae Member): (1) an almost empty NW oriented fracture in SE wall (with only occasional spots of iron oxides, Fig. $1 A$ ); (2) a NE fissure in the south wall (with calcite-sulphide mineralization, Fig. $1 B$ ), both in Väo quarry. The third zone is a vertical body in the Väo and Aseri formations, about $50 \mathrm{~m}$ wide, occurring in a monoclinal fold (felxure) disturbed by fissures in an artificial channel at Harku (Fig. 2). The fourth zone is an extensive horizontal body, about $1-5 \mathrm{~m}$ thick, occurring in the Viivikonna Formation under the Ordovician-Devonian contact in the Narva oil shale opencast (Fig. 3). 
In the quarry the lower and middle parts of the Väo Formation (Rebala and Pae members and the lower part of the Kostivere Member) are exposed in a thickness of $5.8 \mathrm{~m}$. The lower Rebala and upper Kostivere members are characterized by hard grey limestones. The 0.6-m-thick Pae Member is represented by a dark grey porous dolomitized carbonate layer (Fig. $1 A, B$ ). The two alteration zones studied are associated with vertical fractures crosscutting the whole sequence, the Pae dolomite included, and representing regional NE and NW fracture systems. Dolomitization, recrystallization, red-brown colour of rocks, and mineral filling are clearly observable in quarry walls. In the NW oriented fracture zone (Fig. 1A) only iron hydroxides were detected in the fracture walls. The richest mineralization was registered in a $3-10$-cm-thick vertical NE directed fracture in the south wall (Fig. 1B), constituting one in the net of similar veins. Samples were collected from the central mineralization zone, from rocks close to the fractured wall, and unaltered background rocks (at a distance of $1.5-2 \mathrm{~m}$ from the fracture).

The chemical analysis showed that, taking the purest unaltered Väo limestone as a reference field $(<1 \% \mathrm{MgO})$, a high $\mathrm{MgO}$ content in the Pae dolomite occurred only at some distance from the NE oriented fracture (Table, Figs. 1B, 4). Consequently, the same process as described by Kiipli (Кийпли, 1983a) appeared to be present near the NE fracture studied.

In the Rebala and Kostivere members, the dolomitization process in the fracture walls was of rather low intensity and inconstant (Fig. 4). In the empty NW fracture wall, in the primary limestones of the Rebala Member, the $\mathrm{MgO}$ concentration was $4-15 \% ; 2 \mathrm{~m}$ from the fracture it is about $3-8 \%$. In the upper Kostivere Member the wall is not dolomitized. Both in the Pae dolomite layer and fractured walls of Väo quarry, the $\mathrm{FeO}$ and $\mathrm{MgO}$ concentrations show positive correlation (Fig. $5 B$ ). Between the $\mathrm{FeO}$ and $\mathrm{SO}_{3}$ concentrations no correlation was established there. The absence of sulphides in the fracture-related dolomites in $\mathrm{NE}$ Estonia was noted earlier by Pichugin et al. (1978). Obviously, FeO is incorporated into the dolomite crystals, thus pointing to the reductional environments of dolomitization. Red- and brown-coloured rocks near the fractures, especially in the lower part of the Väo section studied, probably contain $\mathrm{Fe}_{2} \mathrm{O}_{3}$ in the form of hydroxides (Fig. 4D). The calcitesulphide vein, filling the fracture, consists of pure calcite and iron sulphide.

\section{Harku outcrop}

In the artificial channel at Harku the Väo Formation is exposed in incomplete thickness of about $4.5 \mathrm{~m}$. The width of the vertical dolomitization zone is about $50 \mathrm{~m}$. The samples were collected from near the surface of the double disc up to the upper border of the Aseri Formation (Fig. 2). In the central part of the zone, the concentration of $\mathrm{MgO}$ changes from 14 to $18 \%$ (Table, Fig. $4 B$ ) and, consequently, the dolomite content reaches $60-80 \%$. Samples of visually unaltered rocks in the outer part of the tectonic zone have the $\mathrm{MgO}$ concentration up to $2-5 \%$. The $\mathrm{FeO}$ content is higher than in unaltered rocks of the Väo outcrop and varies in the limits of $0.7-1.3 \%$. Unlike the Väo site, the $\mathrm{FeO}$ concentration in dolomites of Harku channel depends neither on the $\mathrm{MgO}$ nor on the $\mathrm{SO}_{3}$ concentration (Figs. $5 B, C$ ), although the $\mathrm{SO}_{3}$ content is usually higher at Harku (Fig. $4 E$ ). The concentration of $\mathrm{Fe}_{2} \mathrm{O}_{3}$ is very low in both unaltered and dolomitized rocks. Iron hydroxides are 


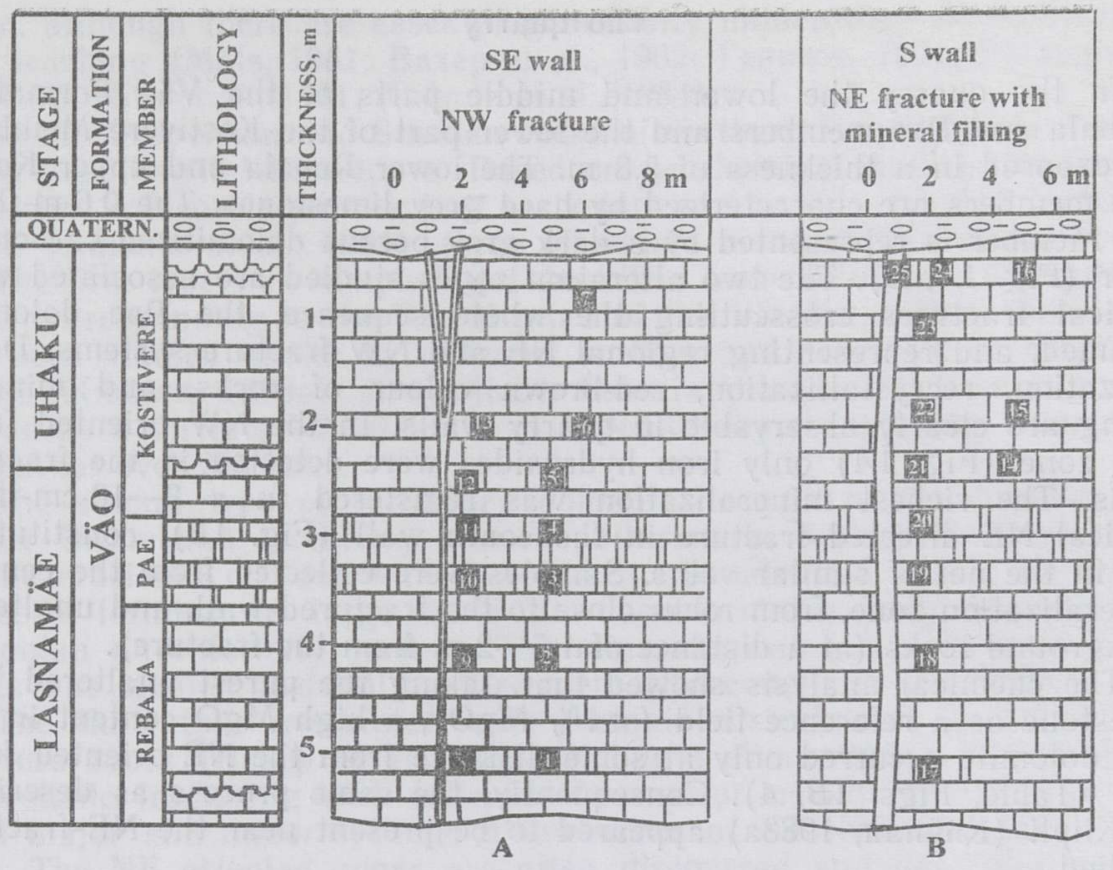

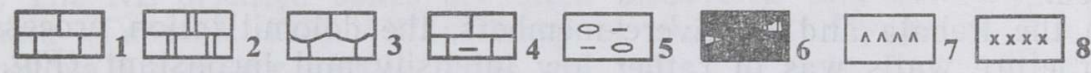

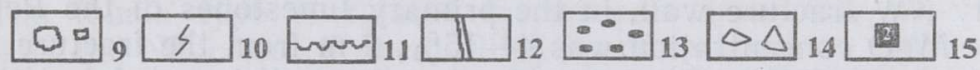

Fig. 1. Section of the Väo Formation in Väo quarry. $A$, sampling scheme of the northwest fracture in the southeast wall; $B$, sampling scheme of the northeast fracture in the south wall.

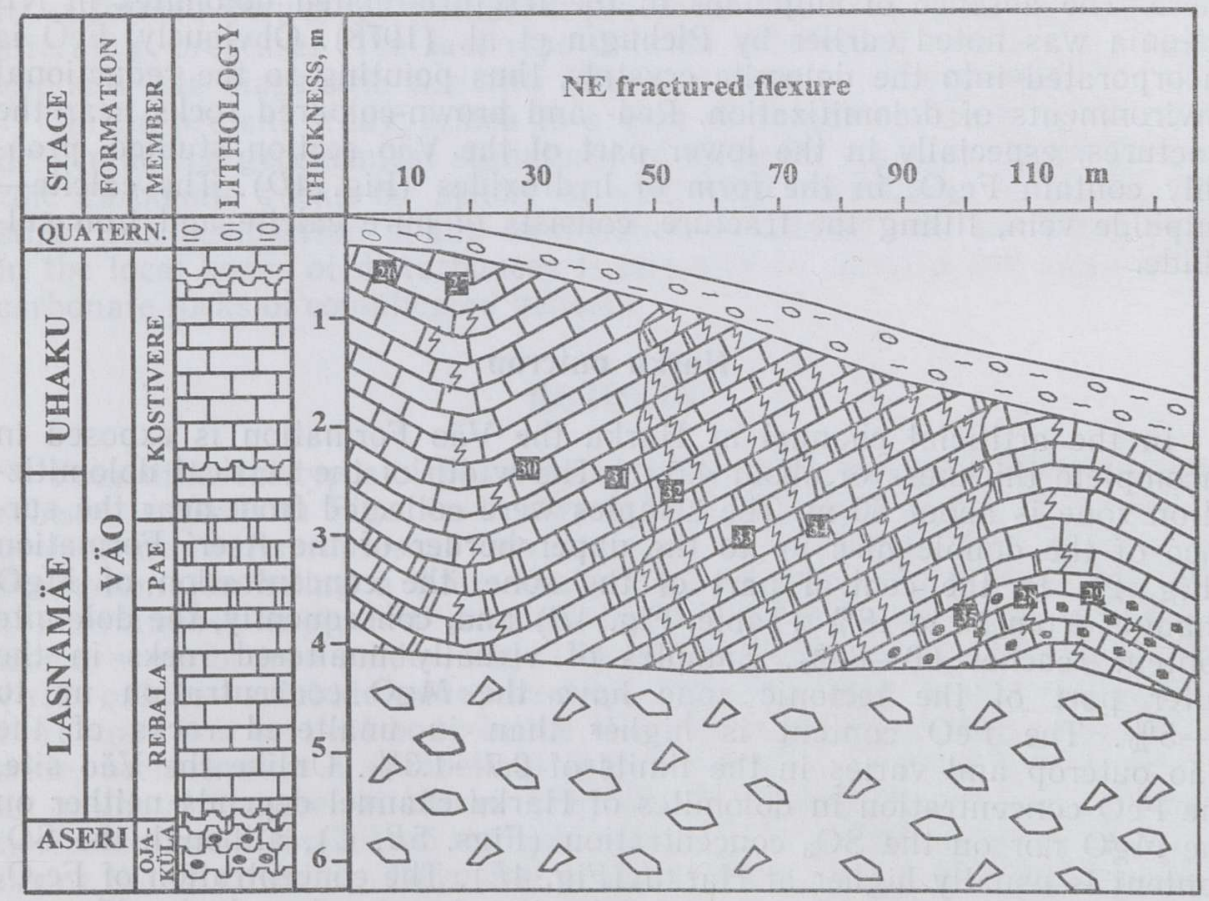

Fig. 2. Section and sampling scheme of the Väo Formation in Harku artificial channel. 82 


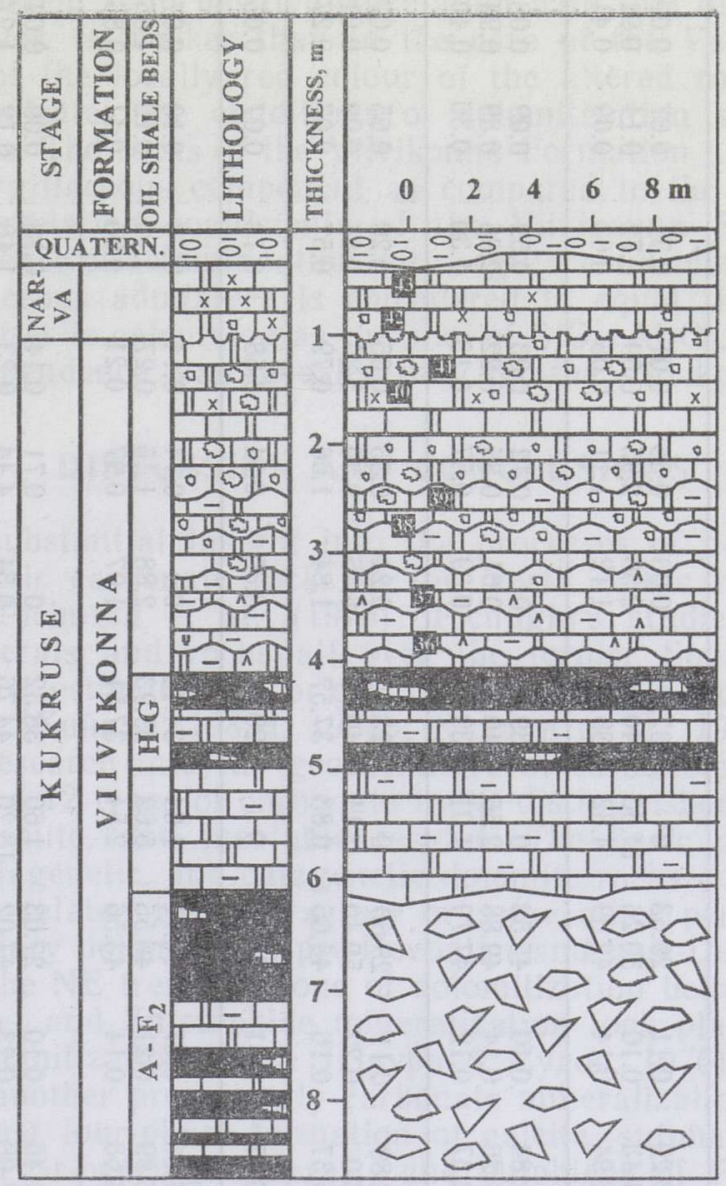

Fig. 3. Section and sampling scheme of the Kukruse Formation in the Narva oil shale opencast.

Legend for Figs. 1-3:

1, limestones; 2, dolomites; 3, lumpy limestone; 4, slightly argillaceous limestone; 5 , Quaternary deposits; 6, kukersite; 7, admixture of kukersite; 8, red-brown rocks; 9, cavernosity; 10, fracturing; 11, discontinuity; 12, fissure; 13, iron oolites; 14, spoil; 15, sampling points.

met only locally independently of the dolomitization degree (Fig. $5 C$ ). This enables us to conclude that high $\mathrm{FeO}$ values are related to its incorporation into the dolomite crystals as described in the case of Aluvere quarry by Pichugin et al. (1978).

\section{Narva outcrop}

In the Narva opencast a laterally extended leached and dolomitized body composed of variably argillaceous limestones and kukersite oil shales was studied below the Ordovician-Devonian unconformity. The section was sampled at the topmost part of the Viivikonna Formation (Kukruse Stage, Fig. 3). The MgO concentration varies between $11-$ $18 \%$ corresponding to the content of mineral dolomite of about $50-80 \%$ (Fig. 4). Close to the Ordovician-Devonian contact, the rocks are partly red-coloured. The total concentration of iron in this section is stable $(0.7$ $-1.9 \%$ ) (Table, Fig. $4 D$ ). The main part of iron occurs in the form of 


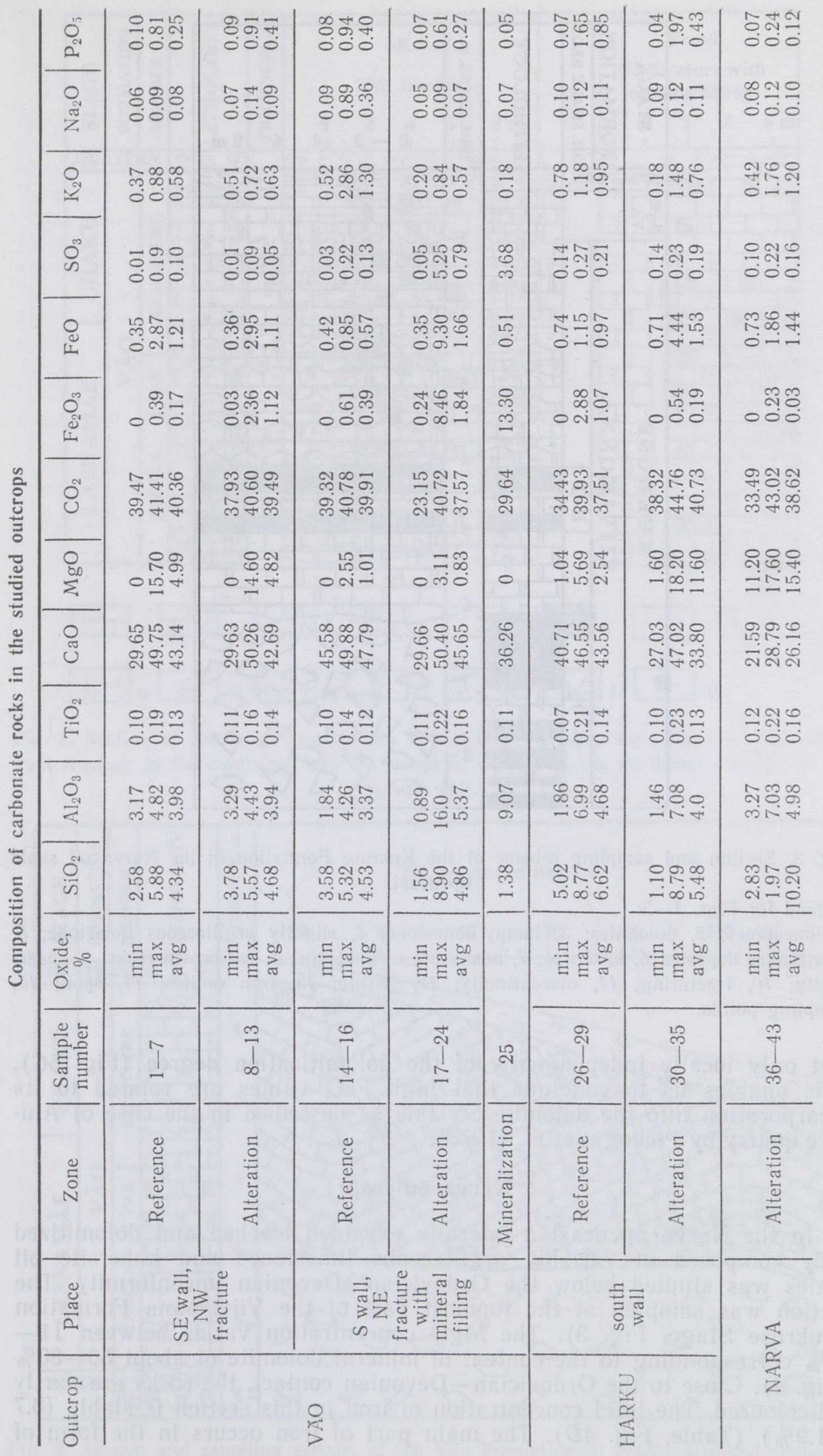


$\mathrm{FeO}$ and its content is in positive correlation with that of $\mathrm{MgO}$. The correlation, however, is weaker than in the case of the Väo outcrop (Fig. $5 B$ ). Despite of the locally red colour of the altered rocks, their main composition indicates the conditions of dolomitization similar to other studied sections. The rocks of the Viivikonna Formation are characterized by a higher argillaceous component as compared to the Väo Formation (Fig. $4 F$ ). Correlation coefficients of the Viivikonna Formation show inverse dependence of dolomitization with argillaceous admixture. The content of argillaceous admixture is considered to equal that of insoluble residue. The latter is calculated as the sum of $\mathrm{SiO}_{2}, \mathrm{Al}_{2} \mathrm{O}_{3}, \mathrm{TiO}_{2}, \mathrm{~K}_{2} \mathrm{O}$, and $\mathrm{Na}_{2} \mathrm{O}$. Such dependence was revealed only for the Viivikonna Formation.

\section{DISCUSSION AND CONCLUSIONS}

The most substantial insight into the processes of dolomitization of Lower Palaeozoic carbonate rocks in the North Baltic region has been published by Pichugin et al. (1978). Pichugin's studies of secondary carbonate minerals and rocks all over the former Soviet Union have permitted us to estimate the origin of metasomatic dolomitization in Estonia. Kiipli (Кийпли, 1983a, 1983b; Кийпли et al., 1984) carried out a systematic research into the geochemistry of carbonate rocks in Estonia. He revealed 12 types of carbonate rocks distinguished by the content of calcite, dolomite, and insoluble residue. The basic classification of sedimentary, diagenetic, and catagenetic dolomite rocks does not differentiate dolomites related to the fracture or some other permeability zone. At least secondary dolomites of pre-Devonian and post-Devonian age can be defined in the NE trending zone of dolomitization between Narva and Pärnu. Fe-, Pb-, and Zn-sulphide mineralization took place there during: the second dolomitization phase (Пуура \& Судов, 1976). Besides dolomitization, in another prevailingly carbonate mineralization process there occurred at least four-phase formation of calcite, sulphates (barite and an unidentified Sr-bearing mineral), and sulphides of $\mathrm{Fe}, \mathrm{Pb}$, and $\mathrm{Zn}$. The most impressive occurrences of fracture-filling mineralization have been documented in the vicinity of Tallinn (Möls, 1961; Niin et al., 1981) and in dolomitized zones of the Narva-Pärnu belt, probably representing there a late calcite-bearing phase (Пуура \& Судов, 1976). The mineralogical variability is first of all expressed by the diversity of crystal cell parameters of dolomite. Geochemically this is caused by the replacing of $\mathrm{Mg}$ by $\mathrm{Fe}^{2+}, \mathrm{Mn}^{2+}$, and $\mathrm{Ca}$ in dolomite (Goldsmith, 1983).

There are different views on the genesis of secondary rocks. The participation of seawater, thermal deep fluids, deep underground water, ordinary ground water, and infiltrating fresh water in alteration processes has been supposed. Different epochs of karstification, starting from the pre-Devonian and pre-dolomitization phase in the Viivikonna area (Baxep et al., 1962) and ending in the Holocene, and solution of recent forms have been revealed in Estonia (Heinsalu, 1977). In the past years the idea of a uniform genesis of secondary dolomites and other altered rocks was prevailing. The geochemical background of dolomite and other carbonate rock formations was interpreted by Kiipli (Кийпли, 1984) considering only the sedimentary conditions of the basin. As shown by mineralogical, lithological, and geological data, the geochemical parameters of dolomitization environments had different characteristics of the thermal field, reduction-oxidation (Eh), and alkalinity-acidity ( $\mathrm{HH})$ potentials.

Analysing the earlier obtained and new results, the following conclusions can be drawn: (1) dolomite formation took place at different times and in different environments; (2) geochemical diversity of fluids 

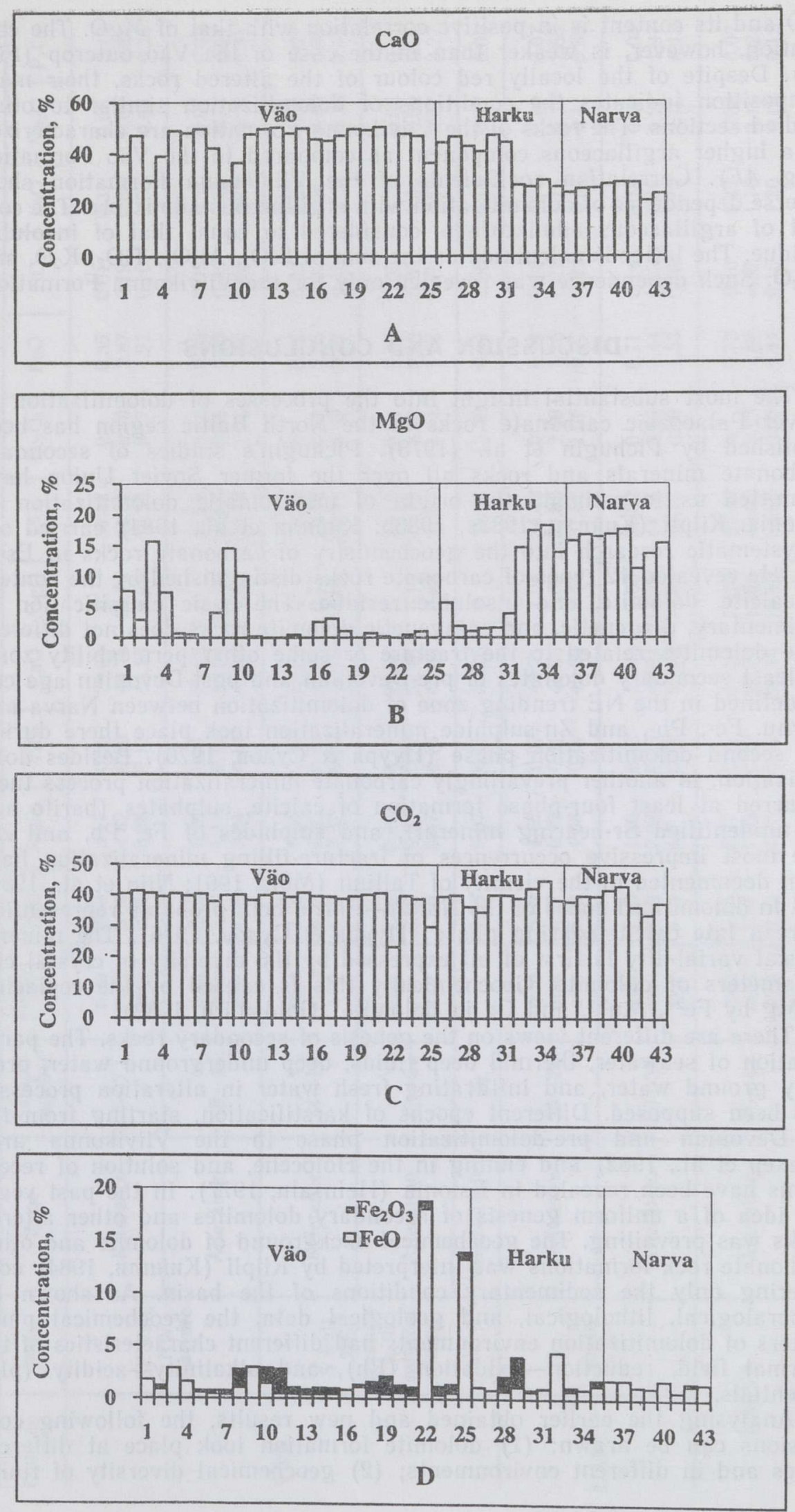

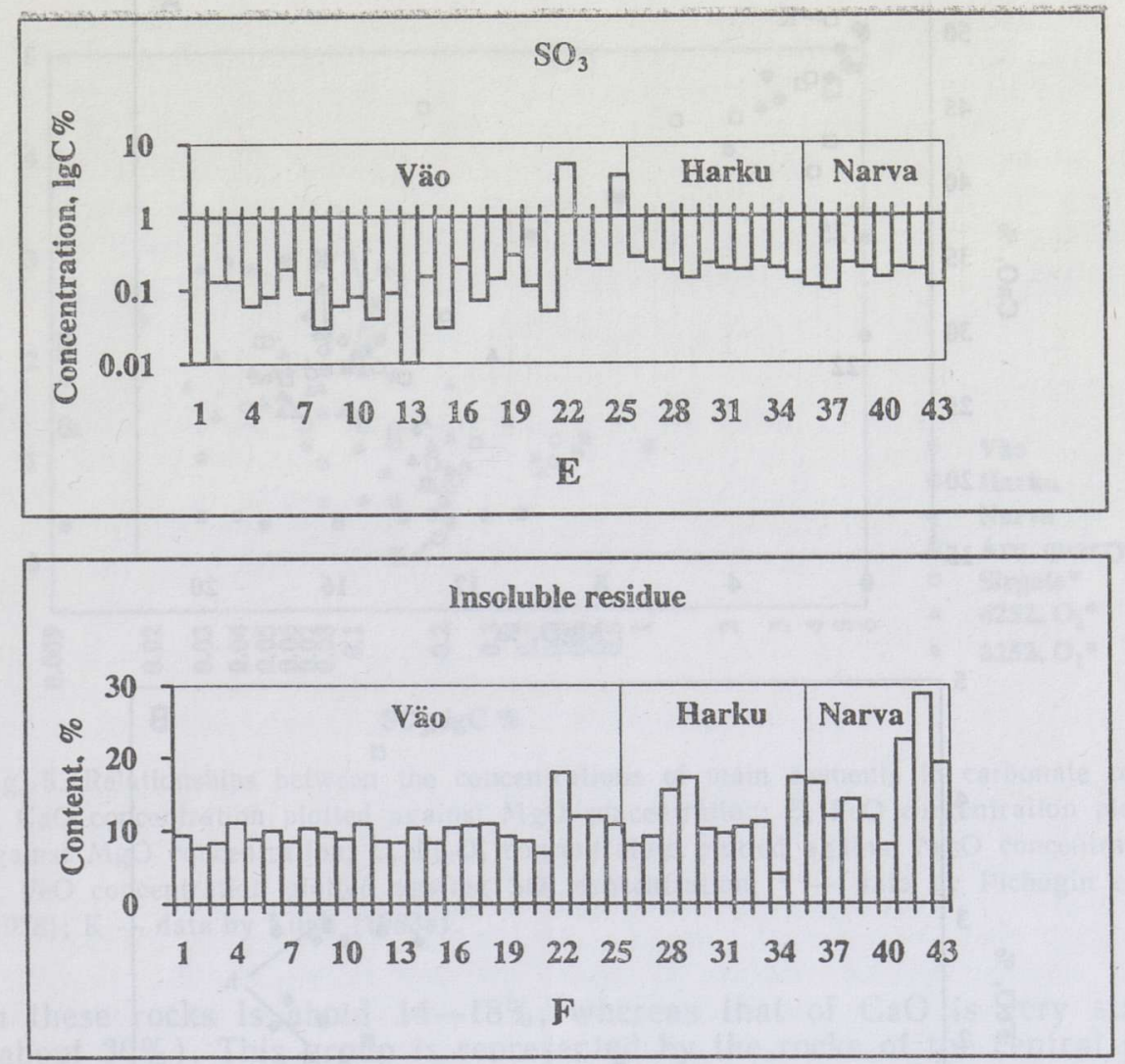

Fig. 4. Histograms showing the distribution of main components of carbonate rocks. $A, \mathrm{CaO}$ concentration; $B, \mathrm{MgO}$ concentration; $C, \mathrm{CO}_{2}$ concentration; $D, \mathrm{FeO}$ and $\mathrm{Fe}_{2} \mathrm{O}_{3}$ concentration; $E, \mathrm{SO}_{3}$ concentration; $F$, insoluble residue content. $1-25$, samples from Väo quarry: background of the NW fracture in the SE wall $(1-7)$, alteration zone of the NW fracture $(8-13)$, background of the NE fracture in the south wall $(14-16)$, alteration zone of the NE fracture $(17-24)$, mineralization zone of the NE fracture (25); 26-35, samples from Harku artificial channel; $36-43$, samples from the Narva oil shale opencast.

was responsible for dolomitization and other types of mineralization; (3) the most carefully studied dolomitization is just one among the alteration processes that occurred in the Lower Palaeozoic carbonate complex of the region. The character and especially geochemical signatures of other secondary processes are still poorly studied.

The comparison of four different altered bodies occurring in the Väo and Viivikonna formations shows a variety of alteration processes in Ordovician carbonate rocks. The chemical composition of the zones under investigation permits us to reveal groups of rocks with a variable degree of dolomitization (Fig. 5A). For example, two clearly different groups may be distinguished by the ratio of $\mathrm{CaO}$ and $\mathrm{MgO}$. The first group includes rocks almost untouched by dolomitization. The concentration of $\mathrm{MgO}$ in these rocks is up to $4 \%$, that of $\mathrm{CaO}$ varies from 42 to $52 \%$. In its composition this group very closely resembles partly dolomitized rocks of the Väo Formation from Väo quarry and those from the marginal parts of the Harku dolomitization zone. The $\mathrm{MgO}$ concentration is there usually below $10 \%$ as in other sites studied by Pichugin et al. (1978). The second group comprises the almost fully dolomitized rocks of the Viivikonna Formation of the Narva opencast. The concentration of $\mathrm{MgO}$ 

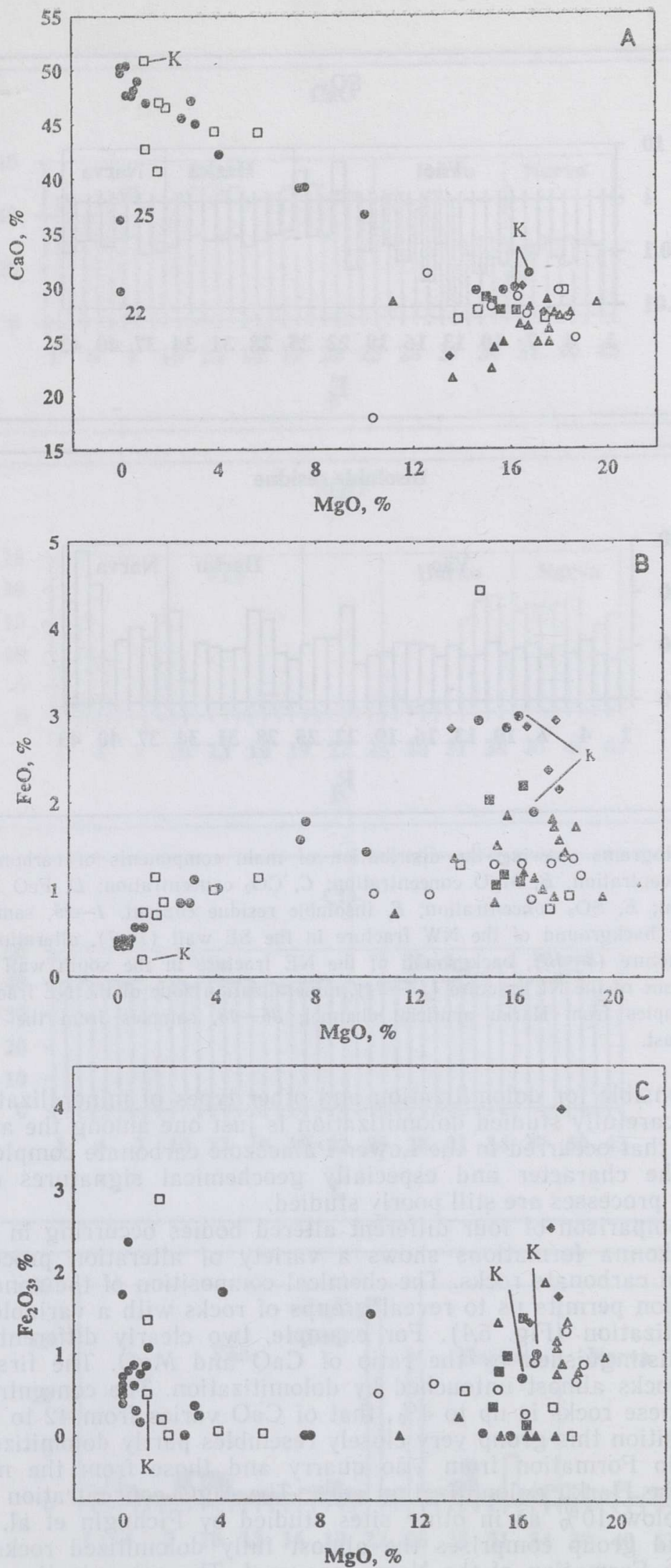

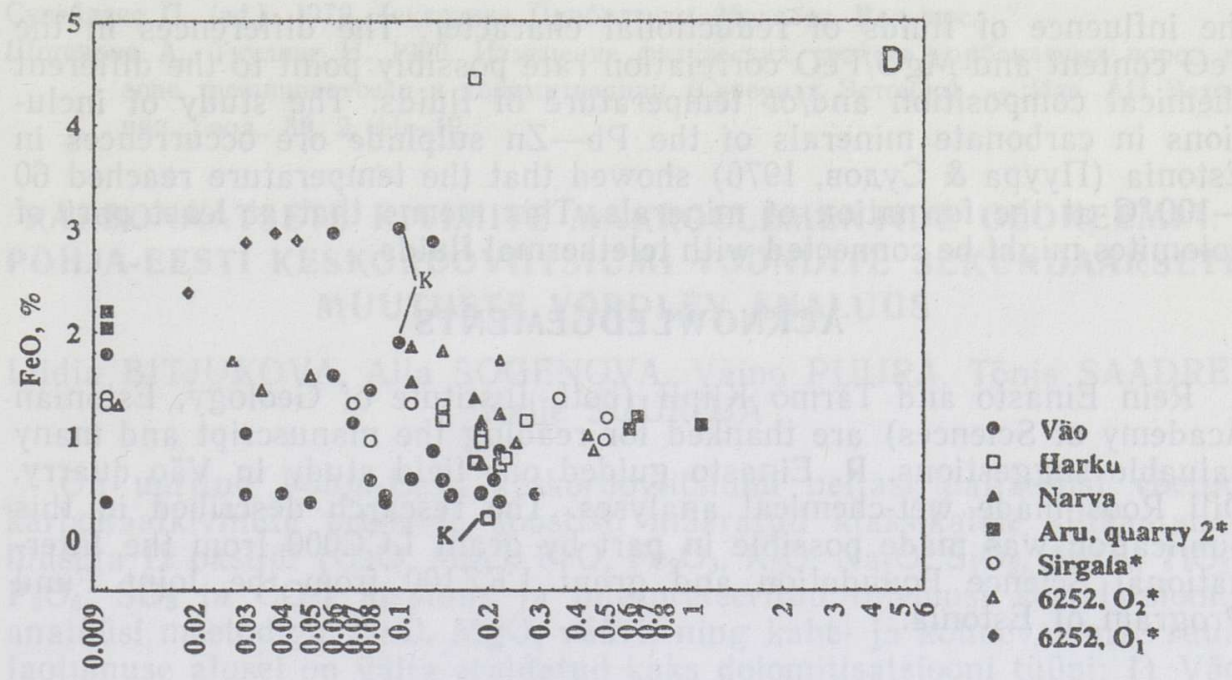

\section{$\mathrm{SO}_{3}, \operatorname{lgC} \%$}

Fig. 5. Relationships between the concentrations of main elements in carbonate rocks. $A, \mathrm{CaO}$ concentration plotted against $\mathrm{MgO}$ concentration; $B, \mathrm{FeO}$ concentration plotted against $\mathrm{MgO}$ concentration; $C, \mathrm{Fe}_{2} \mathrm{O}_{3}$ concentration plotted against $\mathrm{MgO}$ concentration; $D, \mathrm{FeO}$ concentration plotted against $\mathrm{SO}_{3}$ concentration; * - data by Pichugin et al. (1978); K — data by Kiipli (1983a).

in these rocks is about $14-18 \%$, whereas that of $\mathrm{CaO}$ is very stable (about $30 \%$ ). This group is represented by the rocks of the central part of the tectonic zone in Harku artificial channel and also by two samples from Väo quarry (close to the lower border of the dolomite layer of the Väo Formation). The intensity of dolomitization in the studied zones in the Narva and Harku outcrops reaches that of areal dolomitization in the dolomite laver of the Pae Member. However, more statistical material is needed to define the exact limits of the $\mathrm{CaO}$ and $\mathrm{MgO}$ concentration in the above groups and to classify the rocks more precisely. Of substantial help might be the investigation of the $\mathrm{FeO}$ content in dolomitized rocks increasing the number of analyses (Fig. 5B). At present, the dolomite bodies studied differ notably with respect to positive $\mathrm{MgO}-\mathrm{FeO}$ correlation. In the Väo outcrop, for instance, the $\mathrm{FeO}$ concentration increases with that of $\mathrm{MgO}$.

Comparative analysis of our results with the data by Pichugin et al. (1978) showed that the samples studied from Aru quarry 2 belonged to the second group. The same may be concluded for a dolomite zone in the Narva and Sirgala opencasts, although there the FeO content is lower (Fig. $5 \mathrm{~B}$ ). In the samples from the Harku zone of dolomitization studied by us the concentration of $\mathrm{FeO}$ does not increase with the degree of dolomitization. In Estonia FeO predominantly enters the secondary dolomite as confirmed by studies of mineral dolomite (Pichugin et al., 1978), or sulphides in the case of sulphide formation. The latter is confirmed by the positive correlation between $\mathrm{SO}_{3}$ and $\mathrm{FeO}$ for sulphides (samples 22, 25 ), although it is absent in other rocks studied. The content of $\mathrm{Fe}_{2} \mathrm{O}_{3}$ in dolomites is very stable (Fig. $5 \mathrm{C}$ ) and not dependent on the $\mathrm{MgO}$ content. The contents of $\mathrm{SiO}_{2}, \mathrm{Al}_{2} \mathrm{O}_{3}, \mathrm{TiO}_{2}, \mathrm{~K}_{2} \mathrm{O}, \mathrm{Na}_{2} \mathrm{O}$, occurring in the silicate minerals of the argillaceous admixture in carbonate rocks, are only slightly changing in the Väo Formation.

The results described above suggest that the dolomitization process studied in Ordovician carbonate rocks of North Estonia occurred under 
the influence of fluids of reductional character. The differences in the $\mathrm{FeO}$ content and $\mathrm{MgO} / \mathrm{FeO}$ correlation rate possibly point to the different chemical composition and/or temperature of fluids. The study of inclusions in carbonate minerals of the $\mathrm{Pb}-\mathrm{Zn}$ sulphide ore occurrences in Estonia (Пуура \& Судов, 1976) showed that the temperature reached 60 $-100^{\circ} \mathrm{C}$ at the formation of minerals. This means that at least part of dolomites might be connected with telethermal fluids.

\section{ACKNOWLEDGEMENTS}

Rein Einasto and Tarmo Kiipli (both Institute of Geology, Estonian Academy of Sciences) are thanked for reading the manuscript and many valuable suggestions. R. Einasto guided our field study in Väo quarry. Oili Roos made wet-chemical analyses. The research described in this publication was made possible in part by grant LCCO00 from the International Science Foundation and grant LKZ100 from the Joint Fund Program of Estonia.

\section{REFERENCES}

Goldsmith, J. R. 1983. Phase relations of rhombohedral carbonates. - In: Reeder, R. J. (ed.). Carbonates: Mineralogy and Chemistry. Reviews in Mineralogy. Mineralogical Society of America, Washington, 11, 49-96.

Heinsalu, U. 1977. Karst ja looduskeskkond Eesti NSV-s. Valgus, Tallinn.

Männil, R. 1990. Ordovician of Estonia. - In: Kaljo, D. and Nestor, H. (eds.). Field Meeting, Estonia, 1990. An Excursion Guidebook. Tallinn, 21-27.

Möls, E. 1961. Eesti aluspõhja lõhede geneesist. - In: Orviku, K. (ed.). Geoloogiline kogumik. ENSV LUS, Tartu, 5-15.

Niin, M., Niin, S., Puura, V. \& Taalmann, V. 1981. Lõhetäidetest Tallinna ümbruse paemurdudes. - In: Pirrus, E. (ed.). Settekivimid ja tektoonika. ENSV TA LUS, Tallinn, $113-125$.

Pichugin, M. S., Puura, V. A., Vingissaar, P. A. \& Erisalu, E. K. 1978. Regional Metasomatic dolomitization associated with tectonic disturbances in Lower Paleozoic of the Northern Baltic region. - Intern. Geol. Rev. USA, 19(8), 903-912.

Вахер Р., Пуура В., Эрисалу Э. 1962. Тектоническое строение Северо-Восточной Эстонии. - Тр. Ин-та геол. АН ЭССР, 10, 319-335.

Вингисаар П., Таалманн В. 1974. Обзор доломитизации нижнепалеозойских карбонатных пород Эстонии. - Изв. АН ЭССР. Хим. Геол., 23, 3, 237-243.

Газизов М. С. 1958. К вопросу о морфологии и происхождении глубинного карста в Прибалтийском сланцевом бассейне. - Тр. Ин-та геол. АН ЭССР, 20, 133-162.

Газизов М. С. 1971. Карст и его влияние на горные работы. Наука, Москва.

Кийпли Т. 1983а. Доломиты в вяоской свите среднего ордовика Әстонии. - Изв. АН ЭССР. Геол., 32, 2, 60-68.

Кийпли Т. 1983b, О генезисе доломитов ордовика и силура в зоне контакта с перекрывающими отложениями девона. - Изв. АН ЭССР. Геол., 32, 3, 110-117.

Кийпли Т. 1984. Генезис и распространение промышленных залежей малопримесных известняков и доломитов в Эстонской ССР. Автореф. канд. дис. Таллинн.

Кийпли Т., Кивисилла Я., Вингисаар П., Таалманн В. 1984. Эволюция химического состава известняков ордовика и силура Эстонии. - Изв. АН ЭССР. Геол., $33,3 / 4,120-127$.

Клеесмент А., Пылма Л., Каяк К. 1980. Контакт ордовика и девона в Юго-Восточной Эстонии. - Изв. АН ЭССР. Геол., 29, 1, 8-16.

Пуура В., Вахер Р., Туулинг И. 1987. Тектоника. - In: Пуура В. (еd.). Геология и тектоника Раквереского фосфоритоносного района. Валгус, Таллинн, 90-104.

Пуура В., Судов Б. 1976. О зонах платформенной тектонической активизации южного склона Балтийского щита и их металлогенин, - Изв. АН ЭССР, Хим. Геол., $25,3,206-214$. 
Сувейдзис П. (ed.). 1979. Тектоника Прибалтики. Мокслас, Вильнюс.

Шогенова А., Туулинг И. 1990. Изменение физических свойств карбонатных пород в зоне трещиноватости и доломитизации (Северная Эстония). - Изв. АН Эстонии. Геол., 39, 2, 41-49.

\title{
KARBONAATSETE KIVIMITE MAKROELEMENTIDE GEOKEEMIA: PÕHJA-EESTI KESKORDOVIITSIUMI VÖÖNDITE SEKUNDAARSETE MUUTUSTE VÕRDLEV ANALUUUS
}

\author{
Liidia BITJUKOVA, Alla SOGENOVA, Väino PUURA, Tõnis SAADRE, \\ Kalle SUUROJA
}

On uuritud Põhja-Eesti keskordoviitsiumi neljast paljandist võetud karbonaatkivimite proovide koostist, määratud klassikalise silikaatanalüüsiga 12 oksiidi $\left(\mathrm{CaO}, \mathrm{MgO}, \mathrm{FeO}, \mathrm{Fe}_{2} \mathrm{O}_{3}, \mathrm{~K}_{2} \mathrm{O}, \mathrm{Na}_{2} \mathrm{O}, \mathrm{SiO}_{2}, \mathrm{Al}_{2} \mathrm{O}_{3}, \mathrm{TiO}_{2}\right.$, $\mathrm{P}_{2} \mathrm{O}_{5}, \mathrm{SO}_{3}$ ja $\mathrm{CO}_{2}$ ) sisaldus ja interpreteeritud tulemusi korrelatsioonanalüüsi meetodiga. $\mathrm{CaO}, \mathrm{MgO}$, väävli ning kahe- ja kolmevalentse raua jaotumuse alusel on välja eraldatud kaks dolomitisatsiooni tüüpi: 1) Väo kihistu foonilised, peaaegu dolomitiseerumata kivimid Väo karjääris ja Harku paljandis lõhede lähedal ( $\mathrm{MgO} 0-4 \%, \mathrm{CaO} 42-52 \%) ; 2)$ Viivikonna kihistu tugevalt dolomitiseerunud kivimid Narva paljandis ( $\mathrm{MgO}$ $14-18 \%, \mathrm{CaO} \sim 30 \%$ ). Väo ja Narva paljandi kivimites on kindlaks tehtud $\mathrm{FeO}$ ja $\mathrm{MgO}$ positiivne korrelatsioon. $\mathrm{FeO}$ kuulub peamiselt sekundaarse dolomiidi koostisse. Juhul, kui on moodustunud sulfiide, esineb $\mathrm{FeO}$ ja $\mathrm{SO}_{3}$ korrelatsioon. $\mathrm{SiO}_{2}, \mathrm{Al}_{2} \mathrm{O}_{3}, \mathrm{TiO}_{2}, \mathrm{~K}_{2} \mathrm{O}, \mathrm{Na}_{2} \mathrm{O}$ esinevad peamiselt silikaatmineraalide koostises ja nende sisaldus sõltub savilisandi hulgast karbonaatkivimites. Dolomitisatsiooniprotsesside tüpiseerimine jätkub Eesti varapaleosoiliste kivimite edasisel komplekssel geokeemilisel ja petrofüüsikalisel uurimisel.

\section{ГЕОХИМИЯ МАКРОЭЛЕМЕНТОВ КАРБОНАТНЫХ ПОРОД: СРАВНИТЕЛЬНЫИ АНАЛИЗ ЗОН ВТОРИЧНЫХ ИЗМЕНЕНИИ В СРЕДНЕМ ОРДОВИКЕ, СЕВЕРНАЯ ЭСТОНИЯ}

\author{
Лидия БИТЮКОВА, Алла ШОГЕНОВА, Вяйно ПУУРА, \\ Тынис СААДРЕ, Калле СУУРОЯ
}

Изучен состав карбонатных пород, отобранных из четырех обнажений среднего ордовика Северной Эстонии. Определено содержание 12 окислов $\left(\mathrm{CaO}, \mathrm{MgO}, \mathrm{FeO}, \mathrm{Fe}_{2} \mathrm{O}_{3}, \mathrm{~K}_{2} \mathrm{O}, \mathrm{Na}_{2} \mathrm{O}, \mathrm{SiO}_{2}, \mathrm{Al}_{2} \mathrm{O}_{3}, \mathrm{TiO}_{2}, \mathrm{P}_{2} \mathrm{O}_{5}\right.$, $\mathrm{SO}_{3}, \mathrm{CO}_{2}$ ) и дана интерпретация результатов с использованием корреляционного анализа. На основе распределения $\mathrm{CaO}, \mathrm{MgO}$, серы и разновалентных форм железа в породах зон вторичных изменений выделено два типа доломитизации. К первому относятся фоновые, почти не затронутые доломитизацией породы вяоской свиты карьера Вяо и породы этой же свиты вблизи трещин в обнажении Харку (0-4\% MgO, $42-52 \% \mathrm{CaO}$ ). Ко второму типу принадлежат сильно доломитизированные породы вийвиконнаской свиты обнажения Нарва $(14-18 \% \mathrm{MgO}$, $\sim 30 \% \mathrm{CaO}$ ). В породах обнажений Вяо и Нарва установлена корреляция $\mathrm{FeO}$ с $\mathrm{MgO}$. $\mathrm{FeO}$ преимущественно входит в состав вторичного доломита, а в случае образования сульфидов отмечена корреляция $\mathrm{FeO}$ c $\mathrm{SO}_{3}$. Содержание $\mathrm{SiO}_{2}, \mathrm{Al}_{2} \mathrm{O}_{3}, \mathrm{TiO}_{2}, \mathrm{~K}_{2} \mathrm{O}, \mathrm{Na}_{2} \mathrm{O}$, входящих главным образом в состав силикатных минералов, зависит от количества глинистой составляющей в карбонатных породах. Типизация процессов доломитизации будет продолжена при комплексном геохимическом и петрофизическом изучении раннепалеозойских пород Әстонии. 